\title{
CEO Compensation-One Reason Healthcare Costs So Much
}

The Southwestern states were well represented in the category of highest executive pay at non-profit healthcare organizations (1). Leading the way was Bernard Tyson, Chief Executive Officer (CEO) of Kaiser in California, who earned over $\$ 16$ million in salary. Lloyd Dean, CEO of Dignity Health in San Francisco, and Peter Fine, CEO of Banner in Phoenix, also made the top ten at over $\$ 9$ million and $\$ 8$ million respectively. The top 10 are listed in Table 1 and the salaries of the top 50 were all over $\$ 4$ million.

Table 1. Top 10 Healthcare Executives Salary (2017) (1).

\begin{tabular}{lllcc}
\multicolumn{1}{c}{ Executive } & & \multicolumn{1}{c}{$\begin{array}{c}\% \text { other } \\
\text { Position }\end{array}$} & $\begin{array}{c}\text { Salary } \\
\text { compensation }\end{array}$ \\
1 Bernard Tyson & Chairman and CEO, Kaiser Foundation Health Plan and Hospitals, Oakland & $\$ 16,082,753$ & $8.05 \%$ \\
2 & J. KnoxSingleton & President, Inova Health Care, Falls Church, VA & $\$ 14,176,752$ & $58.05 \%$ \\
3 Anthony Tersigni & President and CEO, Ascension, St. Louis & $\$ 13,627,686$ & $8.65 \%$ \\
4 Dr. Rod Hochman & President and CEO, Providence St. Joseph Health, Renton, WA & $\$ 10,533,384$ & $9.42 \%$ \\
5 Lloyd Dean & President and CEO, Dignity Health, San Francisco & $\$ 9,569,824$ & $8.44 \%$ \\
6 PeterFine & President and CEO, Banner Health, Phoenix & $\$ 8,542,030$ & $66.71 \%$ \\
7 Robert Henkel & Executive vice president, Ascension, St. Louis & $\$ 8,125,113$ & $7.25 \%$ \\
8 James Skogsbergh & President and CEO, Advocate Health Care, Downers Grove, IL & $\$ 7,805,356$ & $51.42 \%$ \\
9 Dr. Robert Grossman & Dean and CEO, NYU Langone, New York & $\$ 7,758,904$ & $1.03 \%$ \\
10 Kenneth Samet & President and CEO, MedStar Health, Columbia, MD & $\$ 7,751,857$ & $27.86 \%$
\end{tabular}

However, the salary only tells part of the part of the story. Note that on the far right of Table 1 under the category of other compensation, are some exceedingly high percentages. Adding in other compensation generates the executive total compensation (Table 2).

Table 2. Top 10 Total Executive Compensation (2017) (1).

\begin{tabular}{lllr} 
& Executive & Position & \multicolumn{1}{c}{ Total } \\
1 & Peter Fine & President and CEO, Banner Health, Phoenix & Compensation \\
2 & Dan Wolterman & Special adviser, Memorial Hermann Health System, Houston & $\$ 25,549,644$ \\
3 & Bernard Tyson & Chairman and CEO, Kaiser Foundation Health Plan and Hospitals, Oakland & $\$ 18,957,123$ \\
4 & J. Knox Singleton & President, Inova Health Care Services. Falls Church, VA & $\$ 16,082,753$ \\
5 & Anthony Tersigni & President and CEO, Ascension, St. Louis & $\$ 15,600,777$ \\
6 & Ronald Bunnell & Executive vice president and CAO, Banner Health. Phoenix & $\$ 13,627,686$ \\
7 & Dr. Kenneth Davis CEO, Mount Sinai Health System, New York & $\$ 12,739,075$ \\
8 & James Skogsbergh President and CEO, Advocate Health Care, Downers Grove, IL & $\$ 12,457,914$ \\
9 & Dr. Rod Hochman President and CEO, Providence St. Joseph Health, Renton, WA & $\$ 11,728,456$ \\
10 & Peter McCanna & Executive vice president and COO, Northwestern Memorial HealthCare, Chicago & $\$ 11,583,060$ \\
& & $\$ 11,164,000$
\end{tabular}

Please note that these are all not-for-profit corporations. Economists talk about the pay ratio between CEOs and employees. Comparing Peter Fine's \$25+ million salary with the average primary care physician salary of $\$ 155,212$, a group not generally considered to be undercompensated, which means Mr. Fine earns more in 2 days than a physician earns in a year (2). Fine earns about $\$ 164$ for every $\$ 1$ earned by a physician. 
The people responsible for Mr. Fine's compensation at Banner and other healthcare organizations are the board of directors. At Banner this consists of 13 members and 2 physicians. The physicians are Ronald J. Creasman MD, a retired Gilbert, AZ pulmonologist, and John Koster MD, the retired CEO of Providence Health \& Services in Renton, WA. The others are mostly current or retired corporate executives and many sit on multiple corporate boards.

Steffie Woolhandler, MD, cofounder of nonprofit Physicians for a National Health Program, describes CEO compensation as a misallocation of funds collected for medical services. Overly generous compensation for executives of healthcare organizations diverts resources that would be better spent on patients, Woolhandler told Medscape Medical News in an interview (3). "This is money that is being taken out of the healthcare system and handed over to CEOs. This is money that is not being spent on medications. It is not being spent on doctor visits," Woolhandler said. "It is not being spent on hospitalizations. It's just going in the pockets of these CEOs."

Modern Healthcare reported that the combined compensation for the 25 top paid executives of nonprofit health systems rose to $\$ 197.9$ million in 2017 from $\$ 148.6$ million in 2016 (1). That's a pay increase of 33\% for top executives of nonprofits. In contrast, the average increase was just over 5\% for physicians in 2016 and 2017 (3). The largest increase seen in 2017 for any specialty was $24 \%$ among plastic surgeons. On the other end of the spectrum, pediatricians reported an average salary decrease of $1 \%$ in 2017 (3). Annual gross income for registered nurses was essentially flat, with respondents reporting an average income of $\$ 81,000$ in 2017 and $\$ 80,000$ in 2016, according to the Medscape's 2018 RN/LPN Compensation Report (3).

Overly generous executive compensation can erode the public's trust in healthcare organizations, especially given the growing backlash against aggressive bill-collection tactics, said Martin Makary MD MPH of Johns Hopkins, an expert in healthcare finance (3). Makary questioned the argument that substantial pay packages and increases are needed to attract and keep the best executive talent. Hospitals would do well to consider higher pay for the people who care directly for patients, he said. "What about the talent on the frontline, nurses and doctors? What about the clinicians and the staff at the hospital? Don't we want the best bedside nurses?" Makary said. The compensation packages for executives leading large healthcare nonprofit organizations reflect the market power these systems possess, J. Michael McWilliams, MD, PhD, a professor of healthcare policy at Harvard Medical School, told Medscape Medical News in an email exchange (3).

The increase in healthcare costs has largely been fueled by administrative overhead which now consumes about $40 \%$ of the healthcare dollar (4). The excessive compensation packages for healthcare CEOs and the salaries of their underlings likely contribute to this rising administrative cost. These excessive costs also make accusations against physicians, nurses and other healthcare workers that their salaries are largely responsible for the increase in healthcare costs ring pretty hollow. In order to control costs, understanding where the money is spent is essential. 
In 2016 the Arizona Hospital Executive Compensation Act limiting CEO compensation to $\$ 450,000 /$ year was proposed (5). Although the act was later dropped from the ballot, a survey of Southwest Journal of Pulmonary and Critical Care readers showed that $83 \%$ supported the measure and $35 \%$ though limiting CEO pay would improve patient care. It seems astonishing that so called not-for-profit organizations pay CEOs this amount of compensation. All of the money earned by or donated to a not-for-profit organization should be used in pursuing the organization's objectives and keeping it running. CEO compensation in the millions does not seem to fit these goals.

Richard A. Robbins, MD Editor, SWJPCC

\section{References}

1. Kacik A. Highest-paid not-for-profit health system executives earn $33 \%$ raise in 2017. Modern Healthcare. June, 2019. Available at:

https://www.modernhealthcare.com/executive-compensation/highest-paid-not-profithealth-system-executives-earn-33-raise-2017 (accessed 8/17/19).

2. Banner Health. Banner Health - physicians \& surgeons salaries in the United States. Available at: https://www.indeed.com/cmp/BannerHealth/salaries?job category=meddr (accessed 8/17/19).

3. Young KD. Docs get tiny raises while nonprofit healthcare CEOs get $>\$ 10 \mathrm{M}$. Medscape. August 2, 2019. Available at:

https://www.medscape.com/viewarticle/916423?src=WNL trdalrt 190815 MSCPED IT\&uac=9273DT\&impID=2060646\&faf=1\#vp 2 (accessed 8/17/19).

4. Robbins RA, Natt B. Medical image of the week: medical administrative growth. Southwest J Pulm Crit Care. 2018;17(1):35. [CrossRef]

5. Robbins RA. Survey shows support for the hospital executive compensation act. Southwest J Pulm Crit Care. 2016;13:90. [CrossRef] 